Soler, S. \& Luque, M. O. (2018). Paintings to my ears: A method of studying subjectivity in audio description for art museums. Linguistica Antverpiensia New Series, 17, 140-156.

\title{
Paintings to my ears: A method of studying subjectivity in audio description for art museums
}

\author{
Silvia Soler Gallego \\ Colorado State University, US \\ ssoler@colostate.edu
}

\section{Olalla Luque Colmenero}

Universidad de Granada, Spain

maria1789@hotmail.com

An increasing number of museums are using audio description (AD) to provide access for visually impaired visitors to their collections by means of a wide range of mobile devices and apps. However, research in this field is still limited. The present article proposes a methodological approach that combines interviews and corpus analysis for studying audio-descriptive guides of art museums. More specifically, the proposed methodology focuses on the study of subjectivity, which has become a controversial aspect of $A D$ in the past few years and the focus of a number of studies. The article offers a step-by-step description of the methodology and illustrates it with data from a study carried out by the authors on this type of multimodal communication.

\section{Introduction}

Verbal description and tactile exploration are two accessibility resources used nowadays to improve visually impaired visitors' access to the museum experience (Soler Gallego, 2012 , p. 43). From a translation point of view, verbal description (VD) is defined as a complex cognitive-linguistic and intermodal mediation process (Braun, 2007, p. 358) in which images are translated into words. The aim of this translation process is to enable people with a visual impairment to build a mental image of what they cannot see (Salzhauer Axel, Hooper, Kardoulias, Stephenson Keyes, \& Rosenberg, 2003, p. 229). As regards the medium used, VD can be printed in large fonts or Braille, or conveyed through an acoustic channel - the last of these is termed "audio description" (AD). In the context of museums, AD can be live, recorded or produced by means of text-to-speech software (Díaz Cintas, 2007, p. 50). It is live when used in an audio-described tour of the galleries conducted by a guide. When recorded or produced by text-to-speech software, it is included in an audio-descriptive guide which consists of a collection of audio files that can be accessed online (usually through the museum's website) or via a mobile device.

Some studies have proposed methods to audio-describe visual art in a museum context (De Coster \& Mühleis, 2007; Magalhães \& Santiago Araújo, 2012; Neves, 2012; Santiago Araújo \& de Oliveira, 2013; Soler Gallego, Luque Colmenero, \& Rodríguez Posadas, 2016), while others have described the characteristics of ADs in this context (Cabezas Gay, 2017; Lima \& Magalhães, 2013; Luque Colmenero, 2016; Tomás Rodríguez, 2010). In this second group there are a few studies (Jiménez Hurtado \& Soler Gallego, 2015; Soler Gallego, 2015, 2016, 2018) that not only describe the linguistic features of the ADs, but also formulate explanatory hypotheses of the observed features based on a contextual analysis. The aim of this article is to propose a methodology for studying $\mathrm{AD}$ as used in art museums that follows a similar approach. More specifically, 
the article focuses on our ongoing study of subjectivity in the audio-descriptive guides of art museums.

It is beyond the scope of the present article to offer a detailed exposition and discussion of the results of our study, which will be published in due course. Nevertheless, some results from this study will be used to illustrate the proposed methodology.

After this introduction, section 2 provides an overview of the most relevant research on subjectivity in AD. Section 3 lays out the theoretical tools proposed to study this issue, which are integrated into a methodology that is explained in detail in section 4. Finally, section 5 offers a discussion of the proposal and the conclusions of our work.

\section{Subjectivity in audio-description research}

Subjectivity has become a controversial aspect of $\mathrm{AD}$ because of the inconsistency between some guidelines that recommend a neutral or an objective approach (ADC, 2008; AENOR, 2005; ITC, 2000; Salzhauer et al., 2003; Snyder, 2010) and the benefits that more subjective descriptions seem to have for some people with a visual impairment (RNIB \& Vocaleyes, 2003, p. 52). As stated by Fryer (2016, pp. 165-166), the reasons underlying the objectivist approach-namely, avoiding patronizing practices and allowing people with a visual impairment to build their own interpretation - are positive. However, she adds, guidelines are open to interpretation and can be implemented differently depending on the country.

Some researchers in this field have studied subjectivity in relation to the AD of facial expressions. More than a decade ago, Dosch and Benecke (2004, p. 24, as cited in Mazur \& Chmiel, 2012, p. 178) proposed that detailed physical descriptions such as "He squints, his cheeks are flushed, his lips pressed together" be used instead of making explicit the emotion supposedly felt by the character. In contrast, Vercauteren and Orero (2013, p. 193) consider that emotional language can be used to describe facial expressions that are more universal, according to studies of human cognition, such as those conveying surprise and anger.

As a result of this lack of agreement, subjectivity has become an important topic in reception studies of AD. In the museum context, the Open Art project (Szarkowska, Jankowska, Krejtz, \& Kowalski, 2016) advocates a Universal Design approach, that is, ADs that benefit visitors both with and without a visual impairment. In a reception study that tested this approach for both sighted and visually impaired visitors, it was concluded that visitors to a contemporary art museum prefer shorter, more interpretative descriptions. However, most participants in this particular study did not have a visual impairment, and the study does not comment on the responses to the questionnaires by visually impaired participants. For theatre (Udo \& Fels, 2009; Udo, Acevedo, \& Fels, 2010), the results indicate that audiences of subjective ADs received them a positively as they found them enjoyable and entertaining. For film (Walczak \& Fryer, 2017), the results indicate that more creative ADs may stimulate "presence"-understood here as the suspension of disbelief and perceptual illusion of non-mediation-which in turn would result in a more immersive experience of the film. In a similar study, Ramos (2016) analysed the influence of neutral versus emotional language in $\mathrm{AD}$ on the emotional responses of sighted and visually impaired individuals. The results showed that the ADs that used emotional language elicited stronger responses in both groups. However, in a study on subjectivity in film AD, Mazur and Chmiel (2012, p. 177) found results to be inconclusive owing to the lack of consensus on what constitutes subjective language. Approximately half of the participants considered subjective ADs to be unacceptable. Notwithstanding this, almost three-quarters of them affirmed that they approved of descriptions with evaluative adjectives.

Against the objectivist maxim propounded by most AD guidelines, several scholars have defended an alternative approach to film AD which gives greater visibility to the 
mediating role of audio describers. For film AD, Kruger (2010, p. 233) proposed a scale with three main levels of subjectivity:

- $\quad$ explicitly descriptive $\mathrm{AD}$, which would be closer to the descriptive extreme;

- $\mathrm{AD}$ that supplements description with some narrative markers and subjective interpretation, and

- $\quad$ audio narration (AN) that moves away from strict fidelity to create a coherent narrative, which would be closer to the narrative extreme.

With regard to visual art $\mathrm{AD}$, in their proposal for a method to describe paintings and sculptures, De Coster and Mühleis (2007) highlight the need to interpret and translate both clear and ambivalent visual signs into words. They describe "ambivalent signs" as signs that have several layers of meaning and one of these levels is "visual intensity", which is defined as the sensations produced by the visual sign in the viewer. Along these lines, Neves (2012, p. 290) stated that including more subjective interpretations was necessary so that visually impaired people could experience visual art as sighted people do.

Finally, three descriptive, corpus-based studies of AD in art museums have shown that subjective language is present in the AD of artwork (Lima \& Magalhães, 2013; Luque Colmenero, 2016; Soler Gallego, 2018). However, further studies are necessary to offer a more detailed description of this phenomenon. In the following sections, we introduce our proposal for a methodology to study subjectivity in audio-descriptive guides used by art museums and the theoretical foundations of such a study.

\section{Subjectivity in language and visual communication}

In this section, the theoretical foundations of our proposal are explained, while the next section offers a detailed description of how these theoretical tools are integrated with a corpus-based methodology to study audio-descriptive guides used in art museums. In order to study intersemiotic translation, it is necessary to draw on theories of visual and verbal communication to be able to describe the connection between the non-verbal source text (ST) and the verbal target text (TT).

In the study of $\mathrm{AD}$, cognitive and social semiotic theories should complement each other. In AD studies, various methods of audio describing films have been proposed which draw on cognitive narratology and visual perception theories (Kruger, 2012; Orero \& Vilaró, 2012). Hirvonen (2013) applied the figure-ground alignment cognitive theory to analysing both a film and its AD. Along similar lines, Holsanova $(2016$, p. 68) recently suggested that comparisons of various ADs of the same film should be carried out following a cognitive semantic theory. To date, various studies have proposed a method of audio describing artworks (Araújo \& de Oliveira, 2013; de Oliveira, 2011; Ferreira Aderaldo, 2014; Magalhães \& Araújo, 2012) or have analysed existing ADs (Lima \& Magalhães, 2013) following O'Toole's (2010) adaptation of Functional Grammar to the study of paintings, sculptures and architecture.

We propose that cognitive linguistics and, more precisely, Cognitive Grammar (Langacker, 1987/2008) and its further development by Croft and Cruse (2004) be applied to the study art AD. We consider theories that attempt to describe and explain linguistic communication based on theories of human cognition to be especially relevant to the study of intersemiotic translation phenomena. The reason for this view is that these theories help us to understand the cognitive operations behind the linguistic differences observed in ADs; they also help us to describe AD not only as a linguistic product, but also as a cognitive process that occurs in different languages and cultures.

In Translation Studies, Krüger (2013) and Halverson (2013) have proposed that Langacker's theory of construal be used to study translation shifts. In this theory, 
"construal" is defined as the conceptualization of an entity or a situation as conveyed through language. Alternative construals of the same entity or situation can be created, and the specific features of each construal depend on various human cognitive operations. Croft and Cruse (2004) identify four dimensions of construal based on the main cognitive operation involved in each case: "attention", "judgement and comparison", "perspective" and "overall structure". Each one of these dimensions includes various sub-categories, at least two of which are relevant to the study of subjectivity: "focus of attention" (within the "attention" category), and "metaphor" (within the "judgement and comparison" category).

\subsection{Focus-of-attention dimension in visual art AD}

"Focus of attention" is defined as the selection of conceptual content for linguistic presentation (Langacker, 2008, p. 57). In visual art AD, the audio describer can choose to focus on different elements of the artwork. Table 1 contains a taxonomy of the components of visual communication in art and design, based on the work by Dondis (1974/2006) and Fichner-Rathus (2014). Dondis (2006, p. 13) identifies three levels of communication in visual data: symbol systems, representational visual material, and the abstract understructure. The abstract understructure consists of the basic visual elements, the composition, the style, the medium and the technique, all of which are the formal components of the visual message. The content or meaning of the visual message consists of the iconic signs, the symbolic signs and the concepts, sensations and emotions evoked or triggered by these signs and the formal components (Dondis, 2006, p. 15). For the purposes of classification, we have termed these concepts, sensations and emotions as "opinion". Among the components of visual communication, the audio describer can focus on more objective content only, such as the materials used, the types of shape created by the artist and the stroke width; or also on more subjective content, including the emotions triggered by the colour palette or the concepts evoked by the iconic signs. In other words, she can describe only what she knows that the work contains and conveys or also what the work could contain and convey. We consider the opinion component to be more subjective as compared to the rest, and so we analyse it as an indicator of subjectivity in visual art AD. 
Table 1: Taxonomy of the components of visual communication

\begin{tabular}{|c|c|c|c|}
\hline \multirow{17}{*}{$\begin{array}{l}\text { Visual } \\
\text { communication }\end{array}$} & \multirow{3}{*}{ Content } & \multicolumn{2}{|l|}{ Icon } \\
\hline & & \multicolumn{2}{|l|}{ Symbol } \\
\hline & & \multicolumn{2}{|l|}{ Opinion } \\
\hline & \multirow{14}{*}{ Form } & \multicolumn{2}{|c|}{ Technique } \\
\hline & & \multicolumn{2}{|l|}{ Material } \\
\hline & & \multicolumn{2}{|l|}{ Style } \\
\hline & & \multicolumn{2}{|c|}{ Composition } \\
\hline & & \multirow{10}{*}{$\begin{array}{l}\text { Visual } \\
\text { elements }\end{array}$} & Dot \\
\hline & & & Line \\
\hline & & & Shape \\
\hline & & & Space \\
\hline & & & Dimension \\
\hline & & & Movement \\
\hline & & & Direction \\
\hline & & & Texture \\
\hline & & & Tone \\
\hline & & & Colour \\
\hline
\end{tabular}

To investigate the opinion component further, we draw on Bednarek's work in the field of "evaluation" (also termed "appraisal" and "stance"), which studies the linguistic expression of opinion. Her work differs from other studies in that she creates a connection between linguistic and psychological studies of evaluation and proposes a new model based on a comparative analysis of these two domains (Bednarek, 2009, p. 148). Bednarek draws on the cognitive dimensions of evaluation described by Ellsworth and Scherer (2003) for being common to most appraisal theories that are active in the field of Psychology. Onto this she maps the linguistic dimensions of evaluation proposed by previous linguistic studies. The result is a "classification of 'opinion lexis' that is cognitively motivated" and takes its input both from authentic discourse data and from existing theories of evaluation, trying to offer a cognitive basis for differentiating evaluative dimensions (Bednarek, 2009, p. 161).

This classification comprises seven categories:

- $\quad$ Authenticity (How real/true?)

- Causality (What are the reasons/causes/consequences?)

- $\quad$ Emotivity (How good/bad, and how necessary?)

- $\quad$ Expectedness (How expected?)

- Importance (How important?)

- $\quad$ Power (How easy to deal with, and how comprehensible/complex? How possible? How able?)

- $\quad$ Reliability (How likely?) 
We propose that these categories be used to classify subjective content in corpusbased studies of AD for art museums. They are illustrated below with excerpts from the ADART corpus (opinion lexis indicated in italics; the numbers in this paragraph correspond to the numbered items below). During the analysis, some of these categories were further defined to adapt them to our specific object of study, facilitate the annotation process and provide other researchers in this field with a conceptual tool that can be used to annotate other samples of visual art AD. In this context, Causality refers to opinions in which the audio describer speculates about the technique used by the author, based on the visual components observed in the artwork (e.g., textures, tones) (2). It also refers to concepts evoked by the iconic and symbolic signs and the formal components of the work which might be the concepts that the author intended to convey (3-4). When the opinion expressed is related to the emotions or sensations felt by the viewer or the subject represented in the work (5-6), or conveys an evaluation of artistic quality or aesthetic value (7-8), it is classified as Emotivity. Finally, Reliability refers to expressions of (un)certainty in the categorization of elements of the real world represented in the work (12), except for emotional states (which are categorized under Emotivity).

- $\quad$ Authenticity

(1) The overall look resembles a vigorously brushed watercolour, although it was actually painted with thin oil paints. (Improvisation 31, Kandinsky, National Gallery, Washington)

- $\quad$ Causality

(2) Many colours look as if they were thinly applied to the canvas... (Improvisation 31, Kandinsky, National Gallery, Washington)

(3) His arms are crossed in a casual fashion and he glances up into his right, the viewer's left, as if looking directly at the upper left corner of the canvas. (Man with Crossed Arms, Cézanne, Guggenheim, New York)

(4) The two figures represent the Moon and Earth of the painting's title. (The Moon and the Earth, Gauguin, MoMA, New York)

- $\quad$ Emotivity

(5) This sense of rhythm is heightened by evenly spaced patches of yellow and blueand smaller blotches of red, purple and other colours. (Summertime, Pollock, Tate Modern)

(6) Her face is shown in full profile, her mouth expressionless ... (Woman Ironing, Picasso, Guggenheim, New York)

(7) Watteau's use of red chalk is equally eloquent. (Seated Persian, Watteau, Royal Academy of Arts, London)

(8) His body is slender and boyish ... (The Bather, Cézanne, MoMA, New York)

- $\quad$ Expectedness

(9) Le tableau, de petit format, $80 \mathrm{~cm}$ de hauteur et $64 \mathrm{~cm}$ de largeur, surprend par les contrastes violents de couleurs ... (Jeune Finlandaise, Delaunay, Centre Pompidou) / The small-scale painting (31" by $\left.25^{\prime \prime}\right)$ is surprising owing to the violently contrasting colours ... 
- Importance

(10) Of particular significance is a dark red narrow line that begins just below the figure's waist ... (Woman Ironing, Picasso, Guggenheim, New York)

- $\quad$ Power

(11) El Guernica es una obra de gran complejidad ... (Guernica, Picasso, MNCARS) / Guernica is a highly complex work ...

- Reliability

(12) Three versions of a black boy of perhaps ten or 12 years of age are spread on the page. (Three Studies, Watteau, Royal Academy of Arts, London)

\subsection{Metaphor dimension in visual art AD}

Metaphor is the other dimension of the construal analysed in this study. It is defined as a cognitive operation where an element of reality is compared to a different conceptual domain. "Deliberate metaphor" is a special type of metaphor, and we consider it as another indicator of subjectivity in visual art AD. Compared to the widespread discussion of conventional, automatic and unconscious metaphor in Cognitive Metaphor theory, the concept of deliberate metaphor is an important research innovation. A deliberate metaphor is expressed consciously with a communicative goal and requires a feature to alert the addressee that it is intended as a metaphor (Steen, 2011). Therefore, language users are aware of its being a tool for making a cross-domain comparison (Steen, 2014). In educational discourse, for example, Cameron (2003, p. 119) points out that deliberate metaphors help students to understand concepts that are rather unfamiliar to them.

The analysis of the metaphor dimension follows the MIPVU method developed by the PRAGGLEJAZ Group (see Steen et al., 2010, for a detailed explanation of the method). In this method, expressions whose basic meaning is different from the meaning they have in the text being analysed are marked as potentially metaphorical with the help of different dictionaries and parallel texts. The phases in this analysis can be summarised as follows: (a) reading and comprehending the full text; (b) identifying potentially metaphorical lexical units; (c) identifying a meaning that is more basic than the one they have in the text, and (d) identifying the contextual meaning and checking whether it contrasts with the basic meaning. If it does, but the relationship between the two can be understood from their comparison, the unit is marked as metaphorical. Deliberate metaphors are a special type of metaphor that work as comparisons, are consciously made by the audio describer and are usually flagged with a "marker" (such as "like", "suggesting" and "with the shape of") that draws the attention of the receiver. An example of a deliberate metaphor found in the corpus is "the face like a wild mask" (The Three Dancers, Picasso, Tate Modern) and an example of a non-deliberate metaphor in the corpus is "soft white light" (Home, Mona Hatoum, Tate Modern) (metaphors in italics). The visual component being described is the target domain in the deliberate metaphor operation and the conceptual domain used to describe it is the source domain. To describe this phenomenon further, we propose that a taxonomy based on Simone and Masini's (2014) work on word class be used to classify the source domain. This taxonomy has four supra-categories: object (13), action (14), modifier (15), and characteristic (16). As we can see in the examples from the corpus listed below, the visual image is transferred to a verbal comparison, which lies within the cognitive parcel of the supra-category. 
(13) ... like a beached whale ... (The Persistence of Memory, Dalí, MoMA, New York)

(14) It's dominated by the figure of a young man ... (The Bather, Picasso, MoMA, New York)

(15) The lower half hangs limply over the edge ... (The Persistence of Memory, Dalí, MoMA, New York)

(16) ... his bare arms and torso are unmuscled ... (The Bather, Picasso, MoMA, New York)

\section{Corpora and mixed methods for studying AD in art museums}

During the 1990s, Corpus Linguistics (CL) developed as a methodology of linguistic enquiry within various areas of Applied Linguistics. It was then that a research agenda incorporating this innovative methodology was proposed for Descriptive Translation Studies (DTS). Since that moment, Corpus-based Translation (CBT) has continued developing, and it is now a sound methodology in Translation Studies (Laviosa, 2011, p. 14). This approach was adopted in a method proposed by the TRACCE research team at the University of Granada for studying film AD. This team completed a corpus-based study which used a qualitative data-analysis software program to annotate audiodescribed films at three levels: narratology, film language and grammar (Jiménez Hurtado \& Soler Gallego, 2013; Jiménez Hurtado, Seibel, \& Rodríguez Domínguez, 2010). The methodology proposed in this article draws on the work by TRACCE, but differs from it in that it combines context analysis and corpus analysis. This complementing of corpus data with contextual data was used in a study of subjectivity in interlingual translation, where House (2011) analysed a multilingual corpus along with contextual information collected through bibliographical reviews and interviews. The following section outlines our proposal for a method for corpus compilation and analysis.

\subsection{Corpus compilation and analysis}

A recurrent problem in Corpus Translation Studies (CTS) is the relationship between balance and comparability, on the one hand, and representativeness, on the other (Laviosa, 2011, p. 19). To deal with this issue, it is vital to provide a detailed description of the sample and the population so that the results of the analysis can be considered in context (cf. Soler Gallego, 2012, 2018). To study subjectivity in AD for use in art museums, we compiled a multimodal corpus called the ADART corpus, consisting of the audio-descriptive guides (transcribed audio or script) of 16 art museums in France, the United States, the United Kingdom and Spain, and the corresponding images of the artworks they describe. In the methodology we propose here, Atlas.ti (Scientific Software Development), a qualitative data-analysis software program, is used to annotate and analyse the corpus. First, each section of the guide dedicated to a specific artwork is saved to a separate text file to facilitate the analysis and then it is imported into groups of documents to create sub-corpora for every museum and country, and three styles or levels of abstraction: abstract, semi-abstract and representational. This allows us to analyse later the relationship between subjective content and these variables. Next, customized codes are created and assigned to text segments that are later retrieved through various analysis functions. To further describe the focus of attention and metaphor dimensions, we consider it useful to connect these cognitive-linguistic operations to the ST. For this reason, we propose that the taxonomy of the components of visual communication presented in the previous section be used to classify each element of the artwork being described by means of opinion lexis or a deliberate metaphor (see Table 2). 
Table 2: Groups and codes in Atlas.ti

\begin{tabular}{|c|c|}
\hline Group & Codes \\
\hline $\begin{array}{l}\text { Visual } \\
\text { communication }\end{array}$ & $\begin{array}{l}\text { VC: Content: icon } \\
\text { VC: Content: opinion } \\
\text { VC: Content: symbol } \\
\text { VC: Form: color } \\
\text { VC: Form: composition } \\
\text { VC: Form: dimensions } \\
\text { VC: Form: direction } \\
\text { VC: Form: dot } \\
\text { VC: Form: line } \\
\text { VC: Form: materials } \\
\text { VC: Form: movement } \\
\text { VC: Form: shape } \\
\text { VC: Form: space } \\
\text { VC: Form: style } \\
\text { VC: Form: technique } \\
\text { VC: Form: texture } \\
\text { VC: Form: tone }\end{array}$ \\
\hline Opinion & $\begin{array}{l}\text { Opinion: authenticity } \\
\text { Opinion: causality } \\
\text { Opinion: emotivity } \\
\text { Opinion: expectedness } \\
\text { Opinion: importance } \\
\text { Opinion: power } \\
\text { Opinion: reliability }\end{array}$ \\
\hline Metaphor & $\begin{array}{l}\text { Metaphor: Source Domain: action } \\
\text { Metaphor: Source Domain: characteristic } \\
\text { Metaphor: Source Domain: modifier } \\
\text { Metaphor: Source Domain: object }\end{array}$ \\
\hline
\end{tabular}

To analyse the focus-of-attention dimension of the construal, each text segment containing an opinion is coded or annotated with one of the seven opinion categories, based on lexicographic definitions in different monolingual dictionaries and the contextualized analysis of the text segment (Figure 1). This coded segment or "quotation" (as it is called in Atlas.ti) is embedded into a larger segment coded as the visual component being described. When two or more non-consecutive text segments refer to the same visual component, each segment is treated as a separate quotation and coded as opinion, and all of them are then enclosed within one single quotation that indicates the visual component being described. This allows us to retrieve later the relative word count (percentage) for the opinion category and the frequency (number of occurrences) of this category for each visual component. 


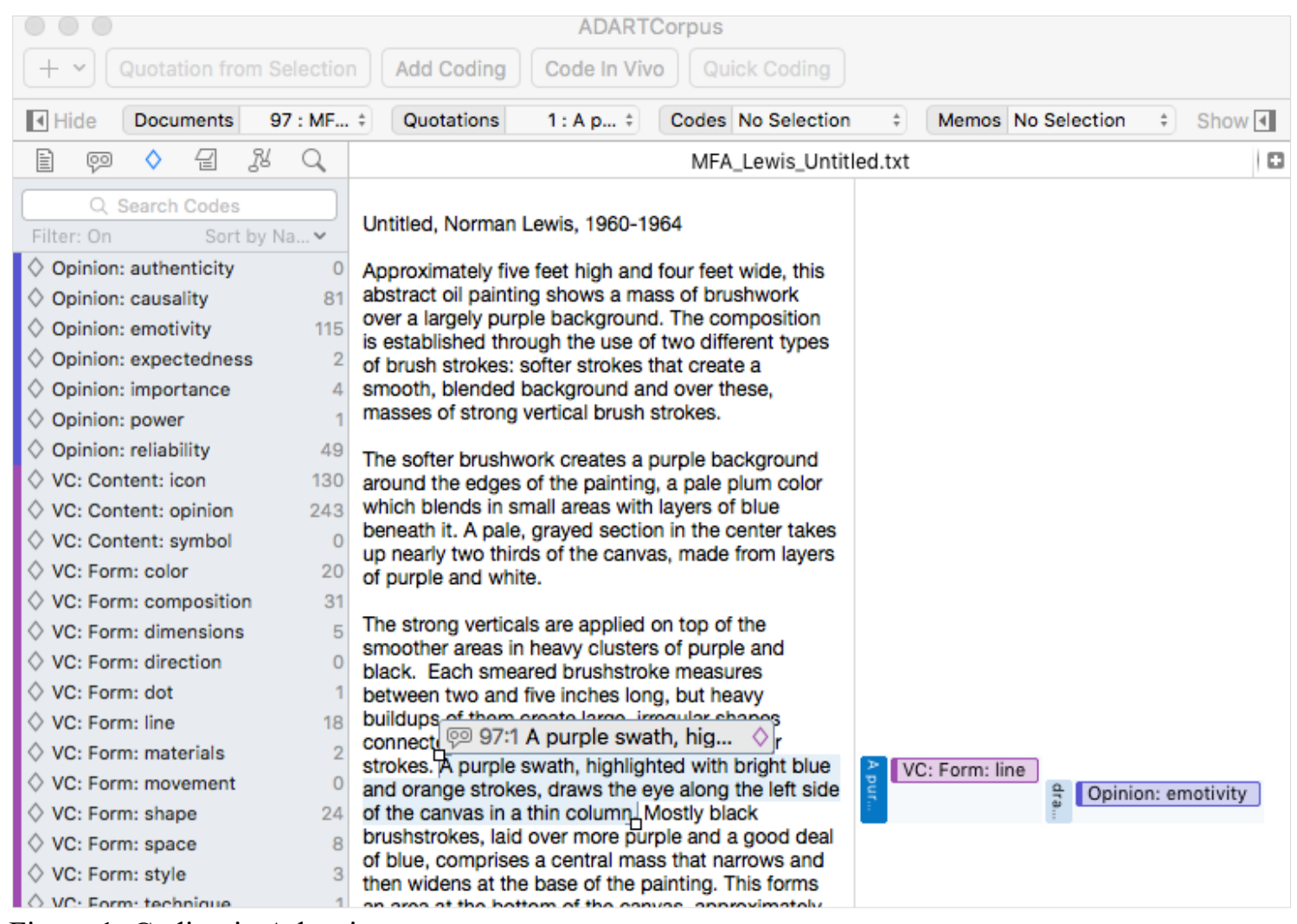

Figure 1: Coding in Atlas.ti

Each text segment containing a deliberate metaphor is coded with one of the four deliberate metaphor categories according to its source domain: object, action, modifier or characteristic. Then this quotation is embedded into a larger quotation that is coded using the component of visual communication being described, according to the taxonomy previously mentioned.

Once the coding process is complete, the "code document table" function within the "analysis" option is used to determine the relative word count for the different opinion and the deliberate metaphor categories - that is, the percentage of the AD that is classified under these categories. This operation is completed for the whole corpus and for any subcorpus. Next, the "quotations enclosing quotations" filter in the "quotations manager" option is used to quantify the co-occurrences of the opinion and deliberate metaphor categories with the categories of the visual components. The "visual communication" codes group is specified as enclosing quotation, whereas the different codes within the deliberate metaphor and opinion groups are specified as enclosed quotations, one at a time. Also, filters for one or several groups of document are added to retrieve data for one specific museum, country or artistic style (see Figure 2). This operation retrieves a list of enclosing quotations together with their code and file. This list is exported as a table to a spreadsheet, where the occurrences of each visual component category are quantified. 


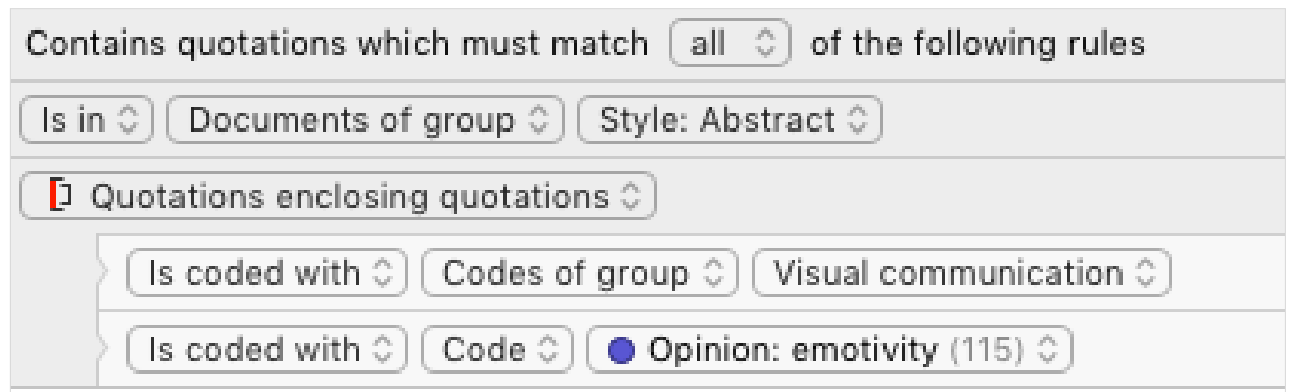

Figure 2: Quotations retrieval in Atlas.ti

Through this analysis, we can obtain results such as the following: in a sub-corpus of audio-descriptive guides of art museums in the United Kingdom and the United States, 58.5 per cent of the metaphor-related words are deliberate and the "object" source domain shows the highest level of deliberateness (see Figure 3 ). In addition, the connection between the opinion content found in the corpus and the components of visual communication can be quantified. In a study of a multilingual corpus comprising audiodescriptive guides of art museums in Spain, France, the United Kingdom and the United States, we concluded that the "opinion" category is related mainly to composition in the ADs of abstract works (see Figure 4). In contrast, in the ADs of semi-abstract and representational art the opinion category is mainly related to iconic signs. In addition to this, it is possible to describe the connection between the visual components (icon, colour, dot, etc.) and the opinion categories (emotivity, causality, etc.) for each artistic style. This method provides not only quantitative data on the presence of subjective content in the corpus, but also a categorization of this content and examples for each category in the corpus.

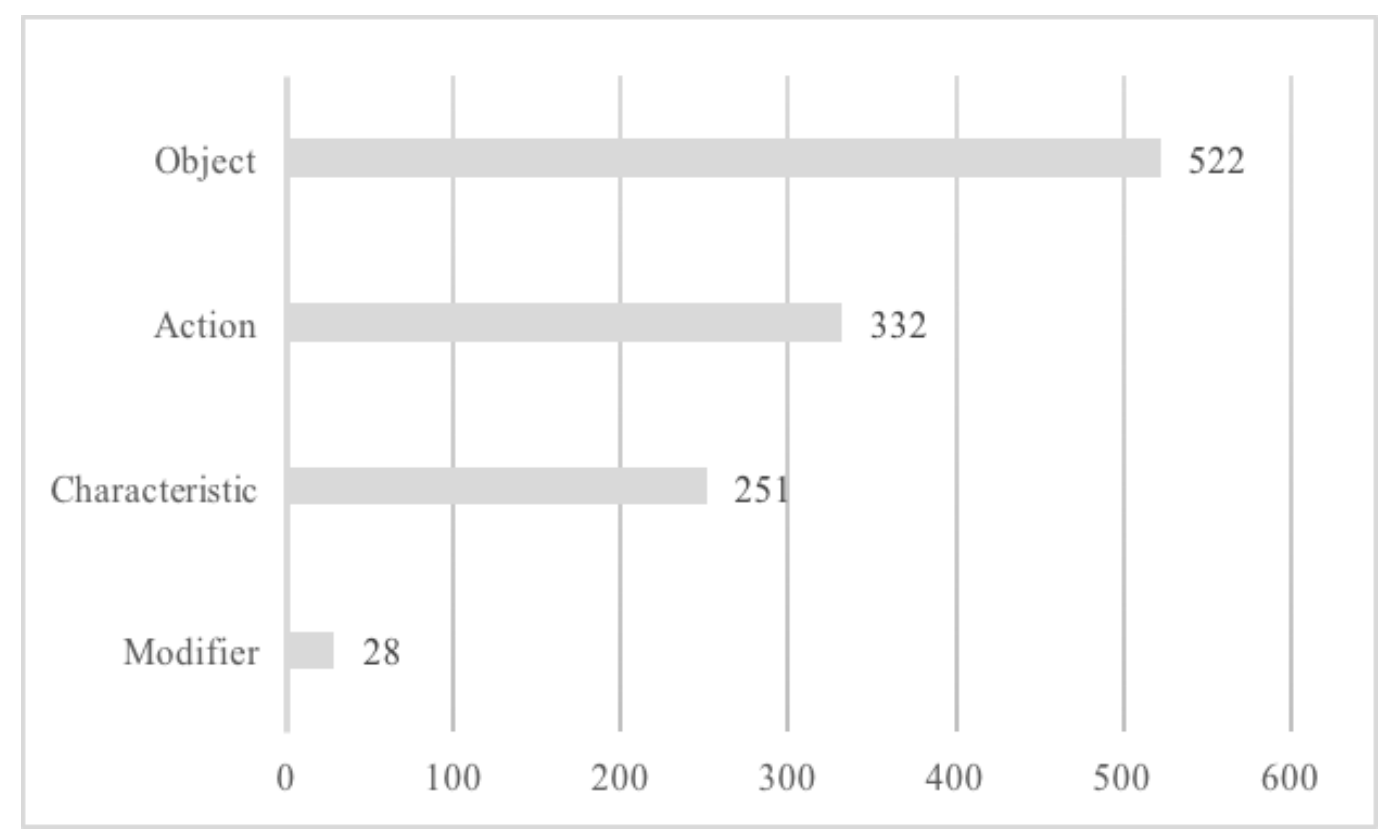

Figure 3: Frequency of occurrence of the deliberate metaphor categories 


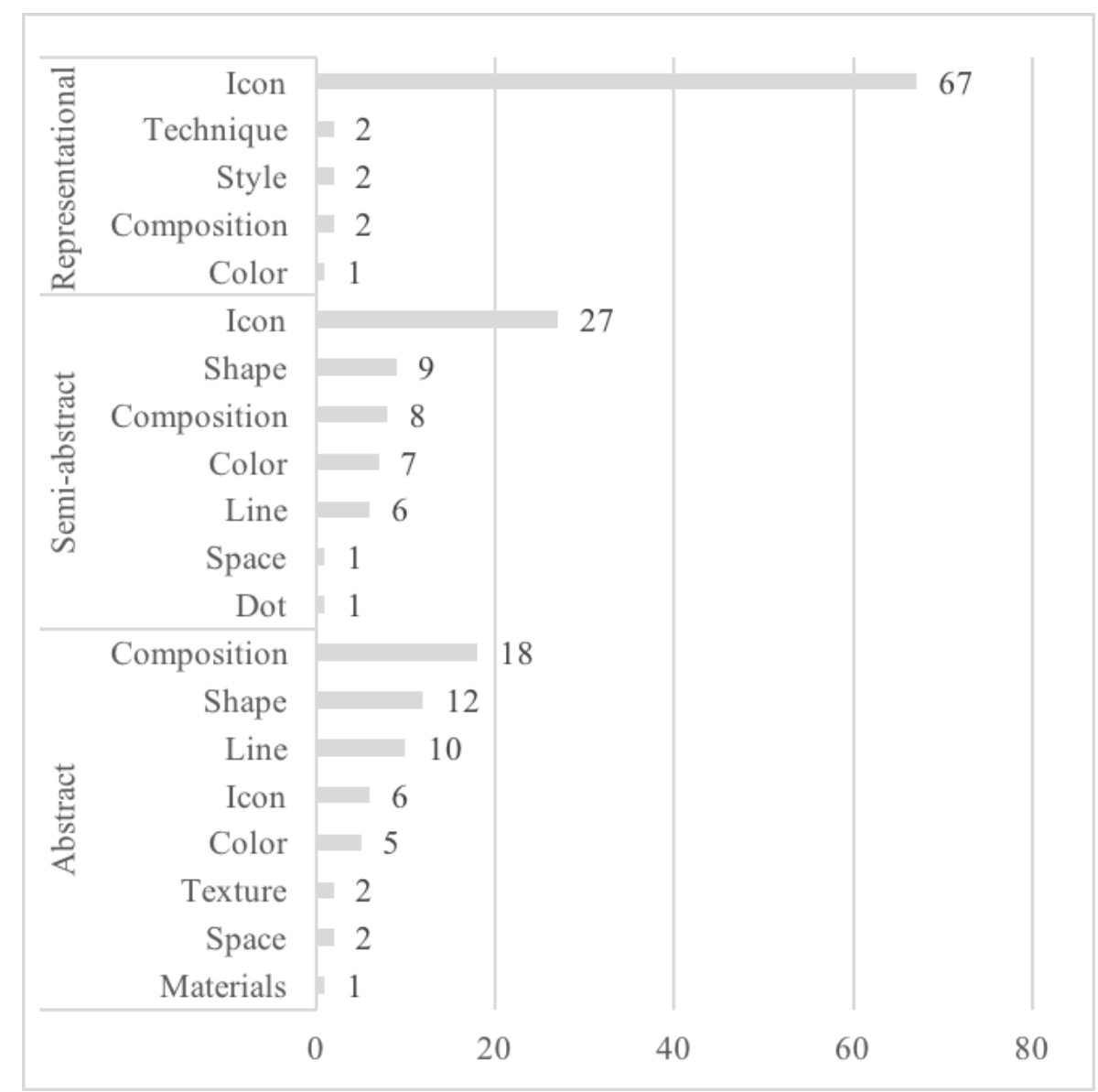

Figure 4: Frequency of opinion content for each visual communication category and artistic style

\subsection{Contextual analysis}

In order to describe the context in which the AD of visual art takes place, it is necessary to collect information from two sources: documents and individuals. The main documentary resources are museum websites and $\mathrm{AD}$ guidelines published by private and public organizations. In addition, it is necessary to interview both the accessibility coordinators and educators working at the art museums included in the study and the professionals and companies involved in the creation of the audio-descriptive guides. If an interview is not feasible, a questionnaire is administered. The interview and the questionnaire start with questions that aim to collect general data about the different projects completed by the participant and the procedure adopted in those projects.

The next set of questions focuses on specific features of AD identified as relevant in most guidelines, in previous research in this area and in the exploratory analysis of the corpus. The full set of questions included in the interview and the questionnaire for museums, companies and freelancers is included below. This basic set is adapted to each participant and to the order in which individuals involved in the same project are interviewed:

- Q1: Who created the audio-descriptive guide for visually impaired visitors for the museum? What is the professional profile of the audio-describer? Were they trained in accessibility and AD? Whom did they receive this training from? 
- Q2: What were the main stages in the development of the audio-descriptive guide for visually impaired visitors?

- Q3: Did the audio-describer follow any set of guidelines to create the ADs? Please specify.

- Q4: If the AD was created by an external company or a freelance audio-describer, how was the collaboration between the museum and the company or the freelance audio-describer? Did the museum give any directions to the company or audiodescriber to create the audio-descriptive guide? Please specify. Did the museum review the contents created by the company or the audio-describer?

- Q5: Was the audio-descriptive guide assessed by consultants with a visual impairment during the creation process?

- Q6: Has the audio guide for visually impaired visitors been evaluated by users? What were the results?

- Q7: Is including both contextual and interpretive information about the work and the AD of the work in the same audio track, instead of including these two types of information in separate audio tracks, beneficial to visually impaired visitors?

- $\quad$ Q8: Which elements of the work are more relevant to visually impaired visitors?

- Q9: Should the language used to audio-describe works of art for visually impaired visitors be as objective as possible?

- $\quad \mathrm{Q} 10$ : Is offering a very detailed $\mathrm{AD}$ of the work beneficial to visually impaired visitors?

A set of codes is created in Atlas.ti to classify the answers to these questions in the audio recordings of the interviews and a "comment" containing a transcription of the answer is added to each quotation (see Figure 5). The quotations for each code are retrieved by means of the "quotations manager" option, along with their code, file name and comment.

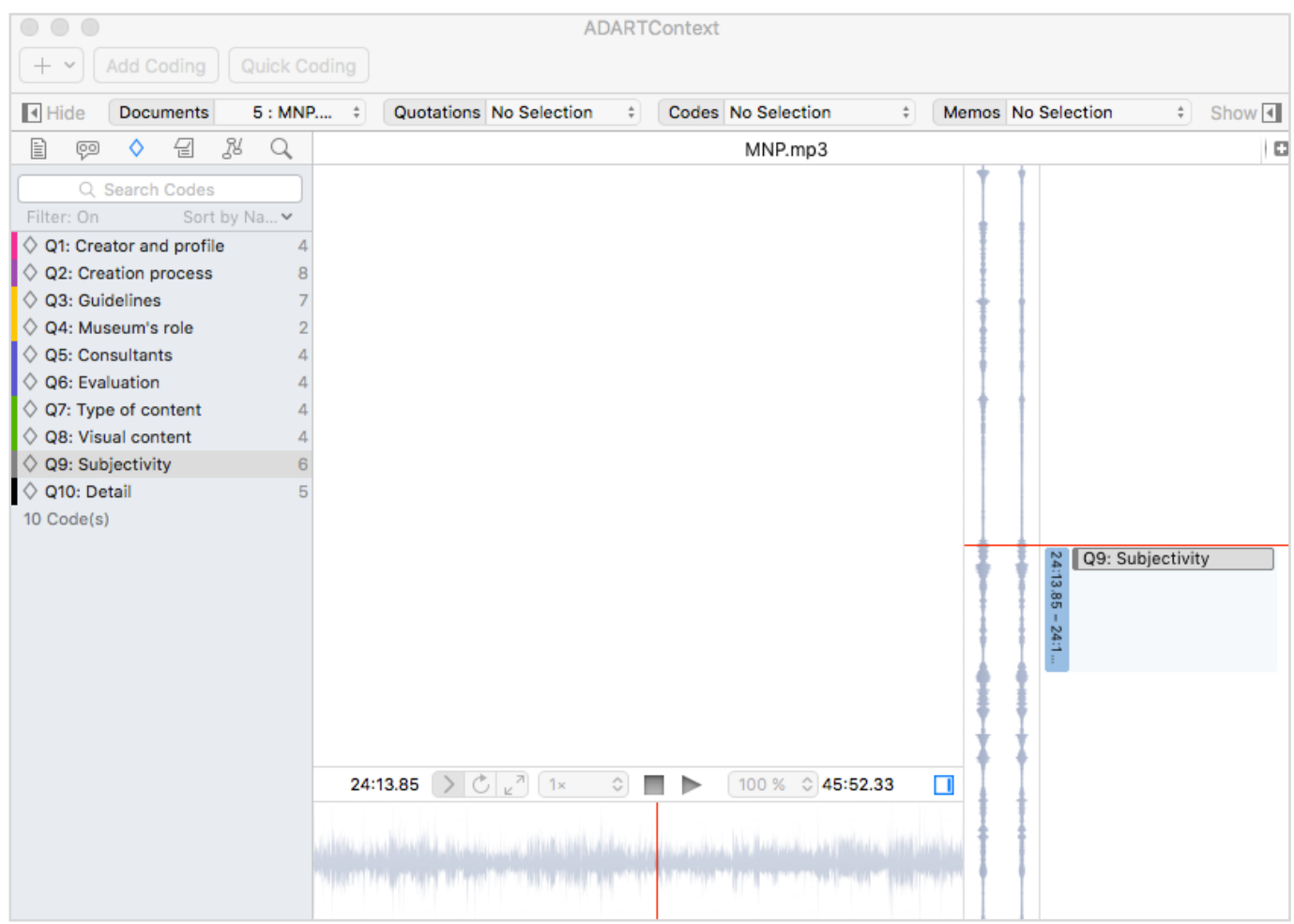

Figure 5: Interview coding in Atlas.ti 
Questionnaires are administered through an online service which includes a function to export questions and answers to a spreadsheet that is combined with the one generated by Atlas.ti.

The discussion of the results of the corpus-based and contextual analyses allows us to formulate explanatory hypotheses of the linguistic features observed in the corpus such as these: the results from the corpus-based analysis indicate that the audio-descriptive guides of the Colchester and Ipswich museums and the Tate Modern are among those in the ADART corpus with a higher a percentage of opinion content. These two British museums are among the seven museums in the corpus with a percentage of opinion content of 20 per cent or higher. This could be related to the fact that the audio describer for the Colchester and Ipswich museums and the accessibility coordinator at the Tate Modern (no data could be collected from the audio describer in this case) defend more subjective ADs. Another contextual factor that could help to explain this data is the existence of less objectivist guidelines for museums in the United Kingdom.

\section{Conclusions}

$\mathrm{AD}$ for art museums is a modality of intersemiotic and multimodal translation and, therefore, it is fundamental that descriptive studies of this translation phenomenon analyse the connection between the visual, non-verbal ST and the verbal TT. In this article, we have shown that a combination of cognitive-linguistic theories, visual communication theories, corpus-based analysis methods and qualitative data-analysis software is a valuable tool for achieving this goal. However, we strongly believe that employing a variety of approaches offers the richest, most useful insight into any translation phenomenon. We hope that the proposed methodology will be combined with other linguistic and visual communication theories to provide different views on AD for visual art. For instance, advocates of O'Toole's (2010) socio-semiotic theory of studying $\mathrm{AD}$ for visual art could use the tools and procedures described in this article to move from case studies to greater collections of real samples of art AD. At the same time, the quantitative data obtained through this methodology should be combined with qualitative data. The analysis functions of Atlas.ti allow for concordance retrieval that makes possible a detailed description of specific linguistic features.

The methodology proposed in this article has been applied to the study of subjectivity in a corpus of audio-descriptive guides of art museums in four different countries. Communication between people owes part of its success to the use of rhetorical and subjective devices that facilitate interactions and play an important role in improving understanding (Gibbs, 1994, p. 34). Subjectivity is a controversial element in the AD of visual art that has become an important object of study in the past decade. However, existing studies of and guidelines for AD have not offered a clear definition of this element. Our proposal focuses on metaphors and expressions of opinion as two indicators of subjectivity. The proposed theories and methods provide us with the necessary conceptual and terminological tools to enter into a more in-depth discussion of this feature. In addition, the theories and methods allow for a systematic analysis though which a more realistic and comprehensive portrait of subjectivity in art AD can be created.

For a descriptive study to be truly useful, it should not be limited to quantitative and qualitative data on the presence and variations of a given feature. A discussion of this feature in its context of communication, based on real data obtained through interviews and similar tools, should be provided and widely disseminated so that current practices can be revised by practitioners and used by other researchers to design reception studies.

The challenge remains how to bridge the gap between descriptive research and professional practice in AD for art museums. Researchers need to identify ways to make their findings more accessible to practitioners and encourage these professionals to think about visual art $\mathrm{AD}$ from different perspectives. One way of achieving this goal is to 
create more opportunities for exchange, such as workshops and conferences co-organized by and intended for both researchers and professionals. In addition, more permanent synergies in the form of research projects and consultancies should be created if the objective of descriptive studies of art $\mathrm{AD}$ is to benefit the individuals for whom this intersemiotic practice came into existence in the first place.

\section{Funding}

This study was carried out as part of the OPERA [Leisure and culture accessibility. Online portal for the dissemination and evaluation of accessible audiovisual resources (FFI201565934-R)] project, and was funded by the Spanish Ministry of Economy, Industry and Competitiveness.

\section{References}

ADC (Audio Description Coalition). (2008). Standards for audio description and code of professional conduct for describers. Retrieved from https://www.nps.gov/hfc/acquisition/pdf/audiodescription/shared/attach-a.pdf

AENOR (2005). Norma UNE: 153020. Audiodescripción para personas con discapacidad visual. Requisitos para la audiodescripción y elaboración de audioguías. Madrid: AENOR.

Atlas.ti (Version 8) [Computer software] Scientific Software Development.

Bednarek, M. (2009). Dimensions of evaluation: Cognitive and linguistic perspectives. Pragmatics and Cognition, 7(1), 146-175.

Braun, S. (2007). Audio description from a discourse perspective: A socially relevant framework for research and training. Linguistica Antverpiensia New Series, 6, 357-372.

Cabezas Gay, N. (2017). Audiodescripción con apoyo táctil en contextos museísticos: Evaluación de una nueva modalidad de traducción accesible. (Unpublished doctoral dissertation). Universidad de Granada, Granada, Spain.

Cameron, L. (2003). Metaphor in educational discourse. London: Bloomsbory.

Croft, W., \& Cruse, D.-A. (2004). Cognitive linguistics. Cambridge: University Press.

De Coster, K., \& Mühleis, V. (2007). Intersensorial translation: Visual art made up by words. In J. Díaz Cintas, P. Orero, \& A. Remael (Eds.), Media for all: Subtitling for the deaf, audiodescription, and sign language (pp. 189-200). Amsterdam: Rodopi.

De Oliveira, N. J. (2011). Ouvindo imagens: A audiodescrição de obras de Aldemir Martins. (Unpublished master's thesis). Universidade Estadual do Ceará.

Díaz Cintas, J. (2007). Por una preparación de calidad en accesibilidad audiovisual. TRANS: Revista de Traductología, 11, 45-59.

Dondis, D.-A. (2006). La sintaxis de la imagen: Introducción al alfabeto visual (Translated into Spanish. Original A Primer of Visual Literacy, 1974). Barcelona: Gustavo Gili.

Dosch, E., \& Benecke, B. (2004). Wenn aus Bildern Worte Werden: Durch Audio-Description zum Hörfilm. Bayerischer Rundfunk: Munich.

Ellsworth, P.-C., \& Scherer, K. (2003). Appraisal processes in emotion. In R.-J. Davidson, K.-R. Scherer, \& H. Hill Goldsmith (Eds.), Handbook of affective sciences (pp. 572-595). Oxford: Oxford University Press.

Ferreira Aderaldo, M. (2014). Proposta de parâmetros descritivos para audiodescrição à luz da interface revisitada entre tradução audiovisual acessível e semiótica social-multimodalidade. (Unpublished doctoral dissertation). Universidade Federal de Minas Gerais. Belo Horizonte, Brazil.

Fichner-Rathus, L. (2014). Foundations of art and design. Boston, MA: Wadsworth.

Fryer, F. (2016). An introduction to audio description: A practical guide. London: Routledge.

Gibbs, R.-W. (1994). The poetics of mind: Figurative thought, language and understanding. Cambridge: Cambridge University Press. 
Halverson, S. (2013). Implications of cognitive linguistics for translation studies. In A. Rojo \& I. Ibarretxe Antuñano (Eds.), Cognitive linguistics and translation: Advances in some theoretical models and applications (pp. 33-73). Berlin: Walter de Gruyter.

Hirvonen, M. (2013). Sampling similarity in image and language: Figure and ground in the analysis of filmic audio description. SKY Journal of Linguistics, 26, 87-115.

Holsanova, J. (2016). A cognitive approach to audio description. In A. Matamala \& P. Orero (Eds.), Researching audio description: New approaches (pp. 49-73). London: Palgrave Macmillan.

House, J. (2011). Using translation and parallel text corpora to investigate the influence of Global English on textual norms in other languages. In A. Kruger, K. Wallmach, \& J. Munday (Eds.), Corpus-based translation studies: Research and applications (pp. 187-208). London: Continuum International.

ITC (Independent Television Committee). (2000). ITC guidance on standards for audio description. Retrieved from http://msradio.huji.ac.il/narration.doc

Jiménez Hurtado, C., \& Soler Gallego, S. (2013). Multimodality, translation and accessibility: A corpusbased study of audio description. Perspectives: Studies in Translation Theory and Practice, 21(4), 577-594.

Jiménez Hurtado, C., \& Soler Gallego, S. (2015). Museum accessibility through translation: A corpus study of pictorial audio description. In J. Díaz Cintas, J. Neves, \& D. Sanchez (Eds.), Audiovisual translation: Taking stock (pp. 279-298). Newcastle upon Tyne: Cambridge Scholars.

Jiménez Hurtado, C., Seibel, C., \& Rodríguez Domínguez, A. (Ed.). (2010). Un corpus de cine: Teoría y práctica de la audiodescripción. Granada: Ediciones Tragacanto.

Krüger, R. (2013). A cognitive linguistic perspective on explicitation and implicitation in scientific and technical translation. trans-kom, 6(2), 285-314.

Kruger, J.-L. (2010). Audio narration: Re-narrativising film. Perspectives: Studies in Translation Theory and Practice, 18(3), 231-249.

Kruger, J.-L. (2012). Making meaning in AVT: Eye tracking and viewer construction of narrative. Perspectives: Studies in Translation Theory and Practice, 20(1), 67-86.

Langacker, R.-W. (1987/2008). Cognitive grammar: A basic introduction. Oxford: Oxford University Press.

Laviosa, S. (2011). Corpus-based translation studies: Where does it come from? Where is it going? In A. Kruger, K. Wallmach, \& J. Munday (Eds.), Corpus-based translation studies: Research and applications (pp. 13-32). London: Continuum International.

Lima, P.-H., \& Magalhães, C.-M. (2013). A neutralidade em audiodescrições de pinturas: Resultados preliminares de um descrição via teoria da avaliatividade. In V.-L. Santiago Araújo \& M. Ferreira Aderaldo (Eds.), Os novos rumos da pesquisa em audiodescrição no Brasil (pp. 73-87). Curitiba: Editora CRV.

Luque Colmenero, M.-O. (2016). The embodiment of the metaphor: An analysis of the metaphors used to convey the human body in audio descriptive guides of museums for people with visual functional diversity. E-AESLA, Revista digital del Instituto Cervantes, 2, 326-334.

Magalhães, C.-M., \& Santiago Araújo, V.-L. (2012). Metodologia para elaboração de audiodescrições para museus baseada na semiótica social e multimodalidade: Introdução teórica e prática. Revista Latinoamericana de Estudios del Discurso, 12(1), 31-55.

Mazur, I., \& Chmiel, A. (2012). Audio description made to measure: Reflections on interpretation in AD based on the Pear Tree Project data. In A. Remael, P. Orero, \& M. Carroll (Eds.), Media for all: Audiovisual and media accessibility at the crossroads (pp. 173-188). Amsterdam: Rodopi.

Neves, J. (2012). A multi-sensory approach to (audio) describing visual art. MonTi, 4, 277-293.

O'Toole, M. (2010). The language of displayed art. London: Routledge.

Orero, P., \& Vilaró, A. (2012). Eye tracking analysis of minor details in films for audio description. MonTI, 4, 295-319.

Ramos Caro, M. (2016). Testing audio narration: The emotional impact of language in audio description. Perspectives: Studies in Translation Theory and Practice, 24, 1-29.

RNIB, \& Vocaleyes. (2003). The talking images guide. Museums, galleries and heritage site: Improving access for blind and partially sighted people. Retrieved from http://audiodescription.co.uk/uploads/general/Talking_Images_Guide_-_PDF_File_5.pdf 
Salzhauer Axel, E., Hooper, E.-V., Kardoulias, T., Stephenson Keyes, S., \& Rosenberg, F. (2003). AEB's guidelines for verbal description. In E. Salzhauer Axel \& N. Sobol Levent (Eds.), Art beyond sight: A resource guide to art, creativity, and visual impairment (pp. 229-237). New York, NY: AFB Press.

Santiago Araújo, V.-L., \& de Oliveira, J.-N. (2013). A pintura de Aldemir Martins para cegos: Audiodescrevendo Cangaceiros. In V.-L. Santiago Araújo \& M. Ferreira Aderaldo (Eds.), Os novos rumos da pesquisa em audiodescrição no Brasil (pp. 89-100). Curitiba: Editora CRV.

Simone, R., \& Masini, F. (2014). New approaches to old word class issues. In R. Simone \& F. Masini (Eds.), Word classes: Nature, typology and representations (pp. 1-14). Amsterdam: John Benjamins.

Snyder, J. (Ed.). (2010). Guidelines for audio description standards. Retrieved from http://www.acb.org/adp/ad.html

Soler Gallego, S. (2012). Traducción y accesibilidad en el museo del siglo XXI. Granada: Ediciones Tragacanto.

Soler Gallego, S. (2015). Painting with words: A corpus study of audio description of art. In L. Carluci \& C. Álvarez del Mercado (Eds.), Insights into multimodal translation and accessibility (pp. 15-35). Granada: Ediciones Tragacanto,

Soler Gallego, S. (2016). A corpus-based genre analysis of art museum audio descriptive guides. In F. Alonso Almeida, L. Cruz García, \& V. González Ruiz (Eds.), Corpus-based studies on language varieties: Linguistic insights (pp. 145-166). Bern: Peter Lang.

Soler Gallego, S. (2018). Audio descriptive guides in art museums: A corpus-based semantic analysis. Translation and Interpreting Studies, 13(2), 230-249.

Soler Gallego, S., Luque Colmenero, M.-O., \& Rodríguez Posadas, G. (2016). Words to see: On the intersemiotic translation of composition in paintings. In A. Rojo López \& N. Campos Plaza (Eds.), Interdisciplinarity in translation studies: Theoretical models, creative approaches and applied methods (pp. 277-294). Bern: Peter Lang.

Steen, G.-J. (2011). When is metaphor deliberate? In N.-L. Johannesson, C. Alm-Arvius, \& D. C. Minugh (Eds.), Stockholm studies in English: Selected papers from the Stockholm 2008 Metaphor Festival (pp. 43-63). Stockholm: University of Stockholm.

Steen, G.-J. (2014). Deliberate metaphor affords conscious metaphorical cognition. Cognitive Semiotics, 5(1-2), 179-197.

Steen, G.-J., Dorst, A.-G., Herrmann, J.-B., Kaal, A., Krennmayr, T., \& Pasmta, T. (2010). A method for linguistic metaphor identification: From MIP to MIPVU. Amsterdam: John Benjamins.

Szarkowska, A., Jankowska, A., Krejtz, K., \& Kowalski, J. (2016). Open Art: Designing accessible content in a multimedia guide app for visitors with and without sensory impairments. In A. Matamala \& P. Orero (Eds.), Researching audio description (pp. 301-320). London: Palgrave.

Tomás Rodríguez, A. (2010). Accesibilidad museística. Audiodescripciones en The Museum of Modern Art, el Museo Nacional Centro de Arte Reina Sofía y el Museo del Romanticismo. Análisis y perspectivas. (Unpublished master's thesis). Universidad de Salamanca, Salamanca, Spain.

Udo, J.-P., \& Fels, D.-I. (2009). "Suit the action to the word, the word to the action": An unconventional approach to describing Shakespeare's Hamlet. Ted Rogers School of Information Technology Management Publications and Research, 16. Retrieved from http://digitalcommonsryerson.ca/trsitm/16

Udo, J.-P., Acevedo, B., \& Fels, D.-I. (2010). Horatio audio-describes Shakespeare's Hamlet: Blind and low-vision theatre-goers evaluate an unconventional audio description strategy. British Journal of Visual Impairment, 28, 139-155.

Walczak, A., \& Fryer, L. (2017). Creative description: The impact of audio description style on presence in visually impaired audiences. British Journal of Visual Impairment, 35(1), 6-7. 